2. Про освіту. Закон України 05.09.2017 p. № 2145-VIII. Дата оновлення: 01.01.2021. URL: https://zakon.rada.gov.ua/laws/show/214519\#Техt (дата звернення: 31.01.2021).

3. Біляй Ю. П. Методична система підготовки майбутніх вчителів математики та інформатики до використання технологій дистанційного навчання : дис. ... канд. пед. наук : 13.00.02. Київ, 2018. 256 с.

4. Радкевич О. П. Теоретичні і методичні основи розвитку правової культури педагогічних працівників закладів професійної освіти : дис. ... д-ра пед. наук: 13.00.04. Київ, 2020. 587 с.

DOI https://doi.org/10.30525/978-9934-26-146-6-23

\title{
ЗАБЕЗПЕЧЕННЯ ЯКОСТІ НАЗЕМНОГО НАВЧАННЯ БОЙОВИМ ПОЛЬОТАМ МАЙБУТНІХ ЛЬОТЧИКІВ ТАКТИЧНОЇ АВІАЦІЇ ЯК ПЕДАГОГІЧНА СИСТЕМА: ОБГРУНТУВАННЯ ПІДХОДУ
}

\author{
Невзоров Р. В. \\ начальник кафедри тактики авіаиії \\ Харківський начіональний університет \\ Повітряних Сил імені Івана Кожедуба \\ м. Харків, Украӥна
}

Надзвичайно стрімкій характер розвитку освітніх процесів з однієї сторони та динамічний прогрес технологій в авіаційній сфері з іншої у XXI ст. чинять об’єктивний вплив на систему фахової підготовки військово-авіаційних спеціалістів в Україні, доповнений новітніми військово-політичними викликами, пов'язаними із загрозою територіальної цілісності й основам національної державності. Реальність, в тому числі, вимагає критичної ревізії підходів, теорії і практики підготовки майбутніх льотчиків тактичної авіації у вітчизняному вищому військовому закладі освіти (в Україні таким профільним закладом, що здійснює підготовку військових льотчиків $є$ Харківський національний університет Повітряних Сил імені Івана Кожедуба). Вказані чинники, а також орієнтир української вищої військової освіти на аналогічний досвід Євроатлантичного Альянсу актуалізують військово-педагогічні дослідження в області забезпечення якості фахової підготовки курсантів-військових льотчиків в цілому та іiї окремих складових зокрема. 
Наземне навчання бойовим польотам якраз $є$ тією складовою їх підготовки у ВВЗО, яка потребує чи не найбільшої уваги в частині науково-педагогічної модернізації й наповнення. В даній царині насьогодні накопичився ряд системних проблем, що потребують негайного розв'язання: по-перше, на рівні державних керівних освітніх документів наземне навчання фактично не унормоване і навіть не визначене, але як складова фахової підготовки льотчиків військової авіації воно активно функціонує в практиці вищого військового закладу освіти; по-друге, у реальній навчальній майбутніх військових льотчиків у ВВЗО України міцно домінують радянські й пострадянські традиції Методики льотного навчання, в якій безумовно превалює психологічна складова та яка морально застаріла відносно сучасного рівня розвитку військової авіації; по-трете, відсутність системного науково-педагогічного підгрунтя у вигляді моделі наземного навчання та обгрунтованої і експериментально перевіреної педагогічної системи забезпечення якості підготовки майбутніх льотчиків тактичної авіації, яка недостатньо компенсована індивідуальною дидактичною практикою льотчиків-інструкторів [2, с. 152]. Якщо перша проблема лежить в площині військово-правової нормотворчості, то друга і третя, на наше переконання, може бути вирішена шляхом розробки, апробації та впровадження відповідної педагогічної системи забезпечення якості наземного навчання бойовим польотам майбутніх льотчиків тактичної авіації.

В рамках авторського підходу до проблеми ми пропонуємо розуміти якість фахової підготовки майбутніх льотчиків тактичної авіації як інтегрований показник відповідності набутих ними професійних компетенцій, фахово значимих вмінь та навичок, а також реальної готовності до виконання бойових задач відносно конкретних вимог Повітряних Сил Збройних Сил України, запитів та очікувань суспільства до сучасних кадрових офіцерів-льотчиків. Виходячи 3 особливостей вищої військової освіти загалом та специфіки фахової підготовки військових льотчиків у ВВЗО вважаємо за потрібне запропонувати увести вказане поняття до категоріального апарату сучасної української військової педагогіки і запропонувати відповідну дефініцію. Якість наземного навчання майбутніх льотчиків тактичної авіації - це системний індикатор теоретичної, передпольотної, психологічної, фізичної, психофізіологічної готовності курсантів-військових льотчиків ВВЗО до спеціально-льотної підготовки до бойових польотів.

Враховуючи складність і багатоаспектність даного поняття, з позицій системного підходу найдоцільнішим вбачається розглядати його в подальшому як окрему педагогічну систему, яка має, відповідно до Загальної теорії систем [4, с. 4-5], системоутворююче ядро (ідеї та 
принципи), структуру (мету, зміст, засоби педагогічної комунікації, суб'єктів, дидактичні засоби та компонентний склад) та відношення i зв'язки між структурними елементами (закономірності, педагогічні умови, освітньо-інформаційне середовище).

Оскільки кінцевою (стратегічною) задачею будь-якого навчання $\epsilon$ досягнення його адекватної якості, а забезпечення якості в організаційно-формальних умовах навчального закладу неможливе без відповідного педагогічного і дидактичного інструментарію та умов, вказана педагогічна система розглядається нами як єдиний можливий операційний засіб досягнення зазначеної мети, що підтверджується на загальному рівні відповідними теоретико-педагогічними дослідженнями [1, с. 17-18; 3, с. 69]. До того ж, існуюча насьогодні у ВВЗО України практика досягнення якості наземного навчання бойовим польотам майбутніх льотчиків тактичної авіації як формально-номенклатурна перевірка відповідності нормативним показникам не враховує складові якості, дані нами у відповідному визначенні, та демонструє свою неефективність.

\section{Література:}

1. Маврин С. А. Педагогические системы и технологии. Омск : Омский государственный педагогический институт, 1993.98 с.

2. Невзоров Р. В. Місце наземного навчання бойовим польотам у системі фахової підготовки майбутніх льотчиків тактичної авіації України. Педагогіка формування творчої особистості у вищій та загальноосвітній школах. Збірник наукових праць. Запоріжжя, 2020. № 71. Т. 1. С. 149-153.

3. Хриков Є. М. Методологія педагогічного дослідження. Харків: ФОП Панов С.В., 2018. 294 с.

4. Bertalanffy L. von. General System Theory - A Critical Review. General Systems. Vol. VII. 1962. P. 1-20. 